\title{
Jole
}

\section{EVALUATING AND EMBODYING EXEMPLARY LEADERSHIP}

\begin{abstract}
Teamwork is essential for patient safety as highly functioning teams make fewer errors. In high acuity academic medical centers, care delivery is complex and ever-changing, creating a high-risk environment for safety concerns. These intricate settings demand a collaborative approach to care delivery, where structured methods of teamwork and communication are engrained in day-to-day practice. With teamwork being a critical component of patient safety and communication failures likened to preventable medical errors, hospitals are looking to bolster leadership training and improve team dynamics. TeamSTEPPS is a proven method shown to enhance teamwork, communication, leadership, and patient satisfaction. TeamSTEPPS provides an evidence-based framework to optimize patient outcomes by improving communication and teamwork skills among healthcare professionals. Current literature on teamwork and communication demonstrates that nurse practitioners are uniquely positioned to improve team performance through the use of the TeamSTEPPS framework.
\end{abstract}

Leadership as a concept and framework has often been discussed in business and in academia from a top-down approach where managers, professors, or those who are already in leadership positions share what they have learned and experienced with men and women who are not in positions of leadership. This sharing of knowledge, wisdom, and experience is incredibly valuable to younger or more inexperienced generations and is one crucial way of developing future leaders in both business and the academic world.

As a business educator and faculty member, I believe students need to also be reading about leadership while they are in school, studying leadership concepts through focused curriculum taught by faculty with leadership experience and training, and through experiential learning practicing relational leadership skills as they envision themselves as leaders in the future (Brungardt, 2011; Grunberg, et al., 2019; Guthrie \& Thompson, 2010; Peterson \& Peterson, 2012; Seemiller \& Priest, 2015). This belief would be in line with other scholars who have documented both the need for, and the practice of a variety of helpful leadership skills and practices in the higher educational classroom (Burns, Diamond-Vaught, \& Bauman, 2015; Kiersch \& Peters, 2017; Klimoski \& Amos, 2012; Wheeler, 2012). Thus, students right now in schools and colleges of business must also be seeking to develop leadership understanding, skills, competencies, and self-confidence through experiential learning exercises if they truly want to manage and impact people in the years to come (Kouzes \& Posner, 2017; Peterson \& Peterson, 2012). 
One cannot give what one does not have, so how can students wake up one day and be effective business, civic, or social leaders if they have not been preparing for these moments and relational engagements? Thus, I am a big believer in experiential learning (a realistic, ongoing process of direct learning from life experiences) projects that help business students' study, evaluate, learn, and seek to live out key and helpful leadership skills, abilities, practices, and strategies right now (Kolb, 2015). I believe the leadership practice for business students is now through experiential learning framed exercises when they are in safe environments within the college classroom where business faculty can teach, mentor, and allow room for mistakes and growth. This intentional leadership teaching helps students discover and hone the areas and ways of leadership that connect to their gifts, talents, passions, and abilities. As Kouzes and Posner (2017) wrote: "leadership is all about how you behave that makes a difference" (p.14). In light of teaching students to think about and act out leadership practices right now, I created this experiential learning project on leadership evaluation and embodiment centered around The Leadership Challenge by Kouzes and Posner (2017) and informed by McCarthy's (2010) experiential learning theory of grounding content in the classroom with learning through experiences.

Experiential learning projects often make content more exciting and engaging for students, and allow for deeper learning in that it bridges knowledge and information with real-world activity and lived out practice (Plump \& Meisel, 2020; Varma, 2020). This specific experiential learning project is rooted in a book, The Leadership Challenge, that suggests anyone can become an effective, and even exemplary leader given one intentionally works at it and engages in specific practices. I have found that this book, content, and experiential project greatly encourages students to think deeply about these practices that make up "The Five Practices of Exemplary Leadership", and helpfully leads students down a path where they can work hard to become an exemplary leader in their vocations as well as personal lives (Kouzes \& Posner, 2017).

\section{Review of Literature}

Leadership is a vast topic in business, management, and in life that covers all sorts of areas or angles of leading and impacting people, including: integrative leadership, transformative leadership, servant leadership, transactional leadership, brand leadership, ethical leadership, relational leadership, and even mentoring (Aaker \& Joachimsthaler, 2000; Crosby \& Bryson, 2010; Dust et al., 2013; Ewen et al., 2013; Harvard Business, 2004; Resick et al., 2013; Tichy \& Ulrich, 1984). In addition, leadership content, attitudes, and practices have also been studied and written about from a power relationship context, organizational behavior context, and even as it relates to professionalism, executive coaching, and modeling professional behavior (Evetts, 2013; Maister, 2000, et al., 2012; Moran, 2009; Northouse, 2019; Schein, 2010). All these forms, angles, and outcomes of leadership all have a helpful and practical place in business and academia, but for students in the classroom, it can often feel overwhelming in knowing where to start to learn more about effective leadership and how to lead. It is for these reasons that I chose The Leadership Challenge for management and business classes that I have taught within AACSB colleges and schools of business in that it is practical, easy to read and follow, yet uniquely deep and thought-provoking in its practices. In addition, this book has been used by many business professors in the classroom, and program directors within colleges and schools of business, and institutes at places like Northwestern University, Rice University, and Santa Clare University (Kouzes \& Posner, 2017). The material in The Leadership Challenge has also been 
presented at over seventy colleges and universities (Kouzes \& Posner, 2017).

Incorporating experiential learning exercises into classroom work helps students work through realworld activities that encourage students to learn through their own experiences and the shared experiences of others around them (McCarthy, 2010). Kouzes and Posner (2017) put forward five specific practices that exemplary leaders follow, and they are: Model the Way, Inspire a Shared Vision, Challenge the Process, Enable Others to Act, and Encourage the Heart. All five of these practices have two "commitments" that comprise each practice, thus showing ten helpful building blocks that teach students intentional, heart and mind engaging leadership practices that impact people professionally and personally (Kouzes \& Posner, 2017). These five practices and The Leadership Challenge book are the backbone of this experiential project.

\section{Description of the Application}

Overview: The project is meant to be used in an undergraduate or graduate management or business class such as: Business Communication, Executive Leadership or Leadership, Managerial Values, Organizational Behavior and Theory, or Principles of Management. The succinct goal of this project is for a student to read all of The Leadership Challenge throughout the course of the semester, then present a 10-minute oral presentation to the class covering three overarching areas of context: Big-Picture Learning and Current Growth, The Impact of the Five Exemplary Leadership Practices (on the heart and mind), and Future Growth Using the Five Exemplary Leadership Practices. This oral presentation is not supported by a power point, rather it is simply speaking to the audience and practicing the professional communication skills connected to effective leadership, personal engagement, and professional articulation of thought (Anderson \& Bolt, 2016; CPE, 2015; Dorch, 2012; Evetts, 2011; Strom \&
Long, 2012; Wiersma, 2011).

Logistics: The Leadership Challenge has 13 chapters that are assigned over 10 weeks; seven weeks students read one chapter each week, and three weeks students read two chapters each week. The final oral presentation which concludes the experiential project is a 10-minute oral presentation.

\section{Step by Step Instructions:}

- On week five, midway through the book, students in class break up into groups of four or five students and discuss what has been the most meaningful and impactful chapters to them personally so far, and which exemplary leadership practices have impacted them the most so far. They do not just share these thoughts, but work to be able to explain the why and because behind what they believe. I remind the students that this discussion time is an intentional time to help them reflect on the content and leadership practices themselves, but it is also designed to get them to personally reflect and prepare their thoughts accordingly for their eventual presentation.

- I use a random generator website to randomize the order of student presenters by last name, and then let students know by week five when they are halfway through reading the book what date they are presenting on.

- Each student prepares a 10-minute oral presentation, with no power point slides, covering all three main content areas of the grading rubric used for the project. Specifically, students will spend one minute introducing themselves and their content, two minutes on their "Big-Picture Learning and Current Growth", three minutes on "The Impact of the Five Exemplary Leadership Practices on their heart and mind", three minutes on their "Future Growth Using the Five Exemplary Leadership Practices", and one minute concluding their thoughts and presentation. 
- As each student is presenting, I use an individual copy of the project grading rubric to grade each student and individual oral presentation in real time.

- I let the entire class know throughout the semester and in the weeks leading up to final presentations that they are welcome and encouraged to schedule a meeting with me during office hours to see their grading rubric from the presentation, hear feedback from me on their presentation through a debriefing time, and reflect on their grasp of "The Five Practices of Exemplary Leadership".

- When students email me to schedule a debrief meeting related to this project, I also ask them to include in the same email a few of their own thoughts related to the book, the project as a whole, and things they enjoyed and did not enjoy about the project. This allows me to not only be able to efficiently schedule debriefing meetings with students during my office hours, but also be able to succinctly capture some student feedback on the project that can inform future iterations of this experiential project in other semesters.

Variations: In online or remote classroom environments, this same experiential project can be accomplished relatively the same way as in a faceto-face classroom environment. In a remote setting, the same steps apply for the project, and the only differences would be student presentations would be live via ZOOM, WebEx, or some other type of video conferencing platform, and student meetings halfway through reading the book would be virtual breakout sessions.

In a purely online environment, the same steps apply for the project except instead of generating presentation days for students, students would record their 10-minute presentation and upload it for the instructor and class by a certain deadline, and student conversation halfway through reading the book could be accomplished through online discussion boards or blog posts. In either online or remote environments, student can still schedule (via email) virtual debriefing meetings with the instructor during office hours.

\section{Learning Objectives and Outcomes}

After engaging in and completing this project, students should be able to:

1. Identify and define all five exemplary leadership practices that make up The Leadership Challenge.

2. Demonstrate an understanding of how The Leadership Challenge helped them grow personally and professionally, and how they will use content that impacted them in their future endeavors.

3. Differentiate the five leadership practices that impacted them the most and be able to articulate which leadership practices were the most valuable to them personally and professionally.

4. Critique their own hearts and minds as they introspectively wrestle with how they want to grow as leaders, and which exemplary leadership practices they want to learn more about and grow in professionally and personally.

\section{Recommendations}

This project is recommended for undergraduate or graduate business students in management and business classes such as: Business Communication, Executive Leadership or Leadership, Managerial Values, Organizational Behavior and Theory, or Principles of Management. This experiential project is grounded in rich content from The Leadership Challenge and "The Five Practices of Exemplary Leadership". This book is highly recommended for use in the classroom also because it contains many helpful leadership stories, valuable real-life examples, 
and related business scenarios that help students not only learn the leadership practices, but also reflect in their own hearts and minds on where they can apply these practices now as growing leaders (Kouzes \& Posner, 2017; Luck \& Swartz, 2020; Peterson et al., 2020). Finally, this project is recommended because it is undergirded by a book and leadership content that has shown to positively impact students, and below are a sample of student feedback quotes from AACSB business students who greatly enjoyed engaging in this book and project:

\section{Quote 1:}

"Throughout this semester I have thoroughly enjoyed reading this Leadership Challenge book. I feel like it has assisted in my personal growth as well as my leadership growth. The presentation we did really showed me how much and what I learned. The presentation experience allowed me to talk through exactly what I learned and things I can improve to become a better more experienced leader."

\section{Quote 2:}

"Having to do this presentation made me really take a look at this entire semester and review all the material. I learned that leaders have many roles and responsibilities on their shoulders. For a leader, it is not all about being the higher person and telling others what to do exactly. As a leader, it is making sure everyone is in a spot they feel comfortable and confident in as well as teaching, encouraging, and helping everyone around you."

\section{Quote 3:}

"When working on my presentation, I realized this: There was a quote I learned this semester about how too much of a good thing, can be a bad thing. After thinking about what that meant for a bit, I realized this goes for these five practices as well. Too much of doing one of these five practices could be a bad thing. For example, challenge the process. If one does not know how to do this in a healthy manner or the right way, it is not going to be as successful."

\section{Quote 4:}

"The biggest positive take away for me from this experience, is what I find most valuable in a leader: which is, Encourage the heart and Challenge the process. I really learned more about who a leader is and the qualities they possess."

\section{Quote 5:}

"The leadership challenge presentation was a good opportunity for me to reflect on the challenges and obstacles faced by people in leadership. As a young leader in my field, I try and take every opportunity to learn and grow in my leadership skills."

\section{Quote 6:}

"Through the presentation, the most helpful thing I learned was not just to read the book, but to take a moment and pause, reflect, and study what I had read. To be able to recall the information and use it in the future would be the goal after reading this book.

\section{Conclusion}

This experiential project is designed to help students evaluate and start to embody leadership practices, creative leadership skills, abilities, and content from The Leadership Challenge (Kouzes \& Posner, 2017; Spivack, 2020). This project is intended to combine a variety of helpful teaching elements related to reading, discussion, oral presentation, reflection, planning, and personal goal setting, and is one helpful and easily implemented classroom project (for face-to-face, remote, or online classroom environments) to help students not just hear about leadership, but intentionally seek to understand and then live out exemplary leadership. It has been a successful and enjoyable experiential project in management and business classes within AACSB educational environments for students and faculty, and the hope is that this project can help other faculty teach leadership and exemplary leadership practices efficiently and effectively while providing opportunities for students to learn through experience (McCarthy, 2010). 


\section{References}

Aaker, D., \& Joachimsthaler, E. (2000). brand leadership. The Free Press.

Anderson, L., \& Bolt, S. (2016). professionalism: skills for workplace success (4th ed.). Pearson Education.

Brungardt, C. (2011). The intersection between soft skill development and leadership education. Journal of Leadership Education, 10(1), 1-22.

Center for Professional Excellence- York College. (January, 2015). national professionalism survey (recent college graduates report). Retrieved from https://www.ycp.edu/media/york-website/studentsuccess/2015-National-Professionalism-Survey---Recent-College-Graduates-Report.pdf

Crosby, B., \& Bryson, J. (2010). integrative leadership and the creation and maintenance of cross-sector collaborations. The Leadership Quarterly, 21(2), 211-230.

Burns, H., Diamond-Vaught, H., \& Bauman, C. (2015). leadership for sustainability: Theoretical foundations and pedagogical practices that foster change. International Journal of Leadership Studies, 9(1)

Dorch, P. (2012). professionalism: new rules for workplace career success. Execudress.

Dust, S., Resick, C., \& Mawritz, M. (2013). transformational leadership, psychological empowerment, and the moderating role of mechanistic-organic contexts. Journal of Organizational Behavior, 35(3), 413-433.

Evetts, J. (2011). a new professionalism? challenges and opportunities. Current Sociology, 59(4), 406-422.

Evetts, J. (2013). professionalism: value and ideology. Current Sociology, 61(5-6), 778-796.

Ewen, C., Wihler, A., Blickle, G., Oerder, K., Ellen, P., Douglas, C., \& Ferris, G. (2013). further specification of the leader political skill-leadership effectiveness relationships: transformational and transactional leader behavior as mediators. The Leadership Quarterly, 24(4), 516-533.

Grunberg, N., Barry, E., Callahan, C., Kleber, H., McManigle, J., \& Schoomaker, E. (2019). a conceptual framework for leader and leadership education and development. International Journal of Leadership in Education, 22(5), 644-650.

Guthrie, K. L., \& Thompson, S. (2010). creating meaningful environments for leadership education. Journal of Leadership Education, 9(2), 50-57.

Harvard Business. (2004). Coaching and mentoring: Harvard Business School Publishing Corporation.

Kiersch, C., \& Peters, J. (2017). leadership from the inside out: student leadership development within authentic leadership and servant leadership frameworks. Journal of Leadership Education, 16(1), 148-168.

Klimoski, R., \& Amos, B. (2012). practicing evidence-based education in leadership development. Academy of Management, 11(4)

Kolb, D. (2015). experiential learning (Second ed.). Pearson Education.

Kouzes, L., \& Posner, B. (2017). The leadership challenge (Sixth ed.). John Wiley \& Sons.

Luck, S., \& Swartz, S. (2020). The textbook didn't mention that: an intercultural experiential exercise in business communication. Management Teaching Review, 5(3), 231-245. 
Maister, D. (2000). true professionalism: The courage to care about your people, your clients, and your career. Touchstone.

Maister, D., Galford, R., \& Green, C. (2012). true professionalism. Simon \& Schuster.

McCarthy, M. (2010). experiential learning theory: from theory to practice. Journal of Business \& Economics Research (JBER), 8(5). https://doi.org/10.19030/jber.v8i5.725

Moran, M. (2009). fostering teacher professionalism in schools (the role of leadership orientation and trust). Educational Administration Quarterly, 45(2), 217-247.

Northouse, P. (2019). leadership: theory and practice (Eighth ed.). Sage Publications.

Peterson, T., \& Peterson, C. (2012). what managerial leadership behaviors do student managerial leaders need? an empirical study of student organizational members. Journal of Leadership Education, 11(1), 102119.

Peterson, C. M., Peterson, T. O., Aikens, S. D., Beard, J. W., Beatty, J. E., Blair, C. A., Lesko, A. P., \& Small, E. E. (2020). story hour in the management classroom. Management Teaching Review, 5(3), 259-264. https://doi. org/10.1177/2379298119836073

Plump, C., \& Meisel, S. (2020). escape the traditional classroom: using live-action games to engage students and strengthen concept retention. Management Teaching Review, 5(3), 202-217.

Resick, C., Hargis, M., Ping, S., \& Dust, S. (2013). ethical leadership, moral equity judgments, and discretionary workplace behavior. Human Relations, 66(7), 951-972.

Schein, E. (2010). organizational culture and leadership (Fourth ed.). Jossey-Bass.

Seemiller, C., \& Priest, K. (2015). the hidden "who" in leadership education: conceptualizing leadership educator professional identity development. Journal of Leadership Education, Summer(1), 132-151.

Strom, B., \& Long, L. (2012). business professionalism: a blueprint to help you analyze, equip, plan, and succeed in the workplace. Charleston, SC: Create Space.

Spivack, A. (2020). recasting the door: an applied design thinking skill building exercise. Management Teaching Review, 5(3), 218-230.

Tichy, N., \& Ulrich, D. (1984). the leadership challenge- a call for the transformational leader. Sloan Management Review, 26(1), 59.

Varma, V. (2020). understanding resistance to change: an experiential exercise. Management Teaching Review, 5(3), 246-258.

Wheeler, D. (2012). servant leadership for higher education. John Wiley \& Sons.

Wiersma, B. (2011). the power of professionalism. USA: Ravel Media. 